\title{
Student Produced Videos - An Innovative and Creative
}

\section{Approach to Assessment}

\author{
Caroline J. Speed ${ }^{1}$, Giuseppe A. Lucarelli ${ }^{2} \&$ Janet O. Macaulay $^{2}$ \\ ${ }^{1}$ Department of Biochemistry and Molecular Biology, Monash University, Australia \\ ${ }^{2}$ School of Biomedical Sciences, Monash University, Australia \\ Correspondence: Dr Caroline J. Speed, Department of Biochemistry and Molecular Biology, Monash University, 3168, \\ Melbourne, Australia.
}

Received: July 3, 2018

Accepted: August 2, 2018

Online Published: August 3, 2018

doi:10.5430/ijhe.v7n4p99

URL: https://doi.org/10.5430/ijhe.v7n4p99

\begin{abstract}
The ability to think critically and creatively are essential graduate attributes for science students yet many science graduates lack these skills and may struggle to gain employment. As undergraduate science educators, we are aiming to improve critical thinking, creativity and the promotion of deeper learning in our students. We have designed and implemented an innovative and creative approach to assessment to engage students with laboratory practicals, which are a core component of the biomedical sciences at Monash University. Through the introduction of an innovative approach to assessment using small group student produced videos, we aim to improve skills in theoretical understanding, data analysis and presentation.

This paper details the design of instructional guidelines for small group student produced video assessment, the implementation of the video assessment into 2nd and 3rd year biochemistry laboratory practical classes and the generation of research outcomes and evaluation of this novel assessment technique. Observation of student behaviour during the laboratory classes found students were filming/photographing their experiments and appeared far more engaged with the actual experiments than in previous years. In addition, many student videos demonstrated high levels of creativity and critical thinking. The student produced video assessment did provide an opportunity for creative and critical thinking in students but there are still aspects to be improved.
\end{abstract}

Keywords: creativity, critical thinking, student engagement, video production, assessment

\section{Introduction}

Science is a creative endeavour with scientists taking creative approaches to discovery, problem solving and inquiry (Hadzigeorgiou, Fokialis \& Kabouropoulou, 2012). Critical thinking is an essential element of deeper learning and an essential attribute of science graduates. Laboratory classes for undergraduate science students at Monash University (a research-intensive university in Australia) were traditionally designed to develop students' technical skills however now address a number of core learning outcomes including the ability to think creatively about problems and demonstrate critical thinking through data analysis and interpretation. Monash University acknowledges the importance of critical thinking in its graduate attributes where it is stated that Monash graduates will be: critical and creative scholars who produce innovative solutions to problems (www.monash.edu.au/pubs/handbooks/alignmentofoutcomes.html). Although significant improvements are being made in the design of laboratory classes (e.g. through the implementation of more inquiry orientated learning) the format of the laboratory class assessment (ie laboratory reports) has generally remained unchanged. Laboratory reports commonly consist of long written reports, a format which scientists do not routinely use in their working lives and which students do not necessarily relate to. Another variation of laboratory reports that have become more common with increasing class sizes are answer sheets - in which students answer specific questions often requiring minimal analysis of the experimental data and missing the "big picture". Hence, there is a need to improve student engagement with the critical thinking and deeper approaches to learning required in the analyses and interpretation of scientific data.

Videos are a media that students are very familiar with and are used routinely in teaching but predominantly as instructional tools and visual aids made available by the teachers. Videos for instructional teaching and demonstrations 
have been used for many years (Fortman \& Battino, 1990) and videos are starting to be used for assessment feedback (Parton, Crain-Dorough \& Hancock, 2010, Henderson \& Phillips, 2015). There is however minimal literature that describes the use of student produced videos as an alternate form of assessment. Some studies report learning "with" videos as opposed to learning "from" videos, in which student produced videos have been introduced as an active learning technique (Jensen, Mattheis \& Johnson, 2012, Kay, 2012, Ryan, 2013, Vanderlelie, 2013, Smith, 2014, Pegrum, Bartle \& Longnecker, 2015, Box et al., 2017). These studies reported the use of student generated videos where students have researched a topic and produced videos for the presentation of their research to replace the more traditional written or oral (face-to-face) presentations used for assessment. Studies in first year chemistry cohorts at a south eastern U.S. university assessed whether technical information was retained at a higher rate after students created a technique video compared to being taught the technique verbally (Erdmann \& March, 2014). Students who produced technique videos demonstrated a higher level of understanding of the technique over students who were taught the technique by verbal means. Studies by Ryan, 2013 on cohorts of second year science students who produced their own instructional videos on biochemistry topics showed that students engaged in their own learning and obtained a deeper understanding of the topics by producing instructional videos.

The availability of simple digital technology such as free video editing software (iMovie, YouTube and Movie Maker) and devices with videoing capability (mobile phones, laptop computers, iPads etc.) now allow us to readily incorporate video production as a learning and assessment tool.

To improve student engagement, critical thinking and deeper learning in undergraduate science laboratory classes an innovative novel assessment strategy using student produced videos was designed and implemented. The student produced videos replaced the traditional science laboratory report writing and had a stronger emphasis on data analysis, critical thinking and creativity. This study utilised existing laboratory protocols in 2 nd and 3rd year undergraduate biochemistry classes with the new innovative video assessment technique. The student produced videos were designed with the aim of fostering critical thinking, collaborative learning and student engagement with biochemistry topics. It is widely accepted that assessment of learning is a critical component of education and that assessment drives/guides student learning through shaping study habits and the approaches taken to learning (Boud \& Associates, 2010, Earl, 2012). Therefore, improved design and implementation of effective and innovative assessment strategies should lead to improved student learning.

\section{Method}

\subsection{Student Cohort}

The students in this study were enrolled in biochemistry units - 2nd year (BCH2022, 230 students) and 3rd year (BCH3042, 74 students). These units could be undertaken within the 3-year undergraduate Bachelor of Science (BSc) or BCH3042 could be taken as an elective within the Bachelor of Biomedical Science (BBiomedSc) program at Monash University, Australia. Each unit was offered as a 12-week semester and was equivalent to 0.125 of the full-time student load for that year. The workload of these units consisted of face-face lectures (2-3 hours per week), and compulsory laboratory classes (3 hours per week). The laboratory classes contributed 30\% (BCH2022) and 20\% (BCH3042) of the unit's assessment.

\subsection{Introduction of "student produced videos"}

One laboratory practical class was selected from each unit to incorporate and trial student produced video reports as the assessment in place of the traditional written reports.

Instructions regarding the assessment of the laboratory classes were provided to the students, via short instructional videos. Instructional videos were used to model the types of videos the students could make. The short introductory videos introduced the laboratory practical exercises and detailed the assessment using student-produced videos. Students were informed that the aims of the video assessment were to improve their theoretical understanding, data analysis, critical thinking and presentation skills and encourage creativity. It was also explained to the students that creativity and critical thinking are important graduate attributes sought after by many potential employers.

Students worked in groups of 2 or 3 when performing the experiments and preparing the video reports. Students were instructed to contribute equally to both making the videos and presenting the results and discussion sections in the videos. There were no specific technical requirements for how students recorded and edited their videos. Students could use any type of video recording device available to them (e.g. smartphone, webcam on their laptop, etc.) and whichever type of software they chose. A time limit of 5-10 minutes for the video was included to encourage the students to present and critically analyse their data in a clear and concise manner. For each unit a specific student forum was set up 
on Monash University's virtual learning environment, Moodle, to allow for discussion of any technical issues students had. One of the authors (GAL) was designated to respond to these forums.

Videos were submitted individually by each student on Moodle, in an MP4 format.

Specific guidelines for students required that the video must include:

- a title with student names as a caption (up to 30 seconds);

- an introduction where both students presented themselves in front of the camera followed by a brief introduction of the topic (what is the topic of your video?) (up to $1 \mathrm{~min}$ );

- results and discussion - this was to encompass the bulk of the video and therefore most of the students' effort was to be spent in developing this section. This section was required to include:

- name of main techniques used and an explanation of why these techniques were used;

○ experimental design (i.e., conditions tested, controls included);

○ results obtained;

- critical discussion of the results.

As the student videos were incorporated to encourage creativity, a creative pictorial representation of the process for developing the videos and engaging in critical thinking, collaborative learning and developing communication skills was designed (Figure 1).

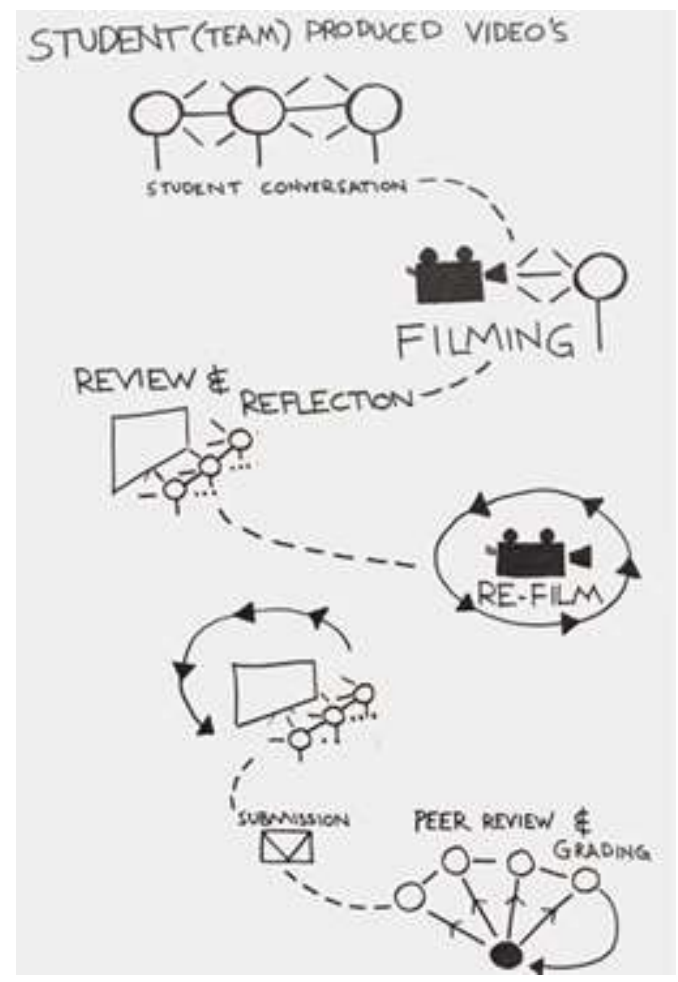

Figure 1. Diagrammatic representation of the process of the production of the student produced videos.

Both student cohorts had two weeks to complete their practical class across 2 x 3-hour sessions. Students were encouraged to film and photograph their experiments to include in their video reports. Students then had 2 weeks $\left(2^{\text {nd }}\right.$ year) or 1 week $\left(3^{\text {rd }}\right.$ year) to work in their pairs to complete their videos for submission.

A marking rubric was developed to assess the overall practical classes (Figure 2). The rubric assessed a range of attributes associated specifically with the videos including the quality of the video (audio, visuals, timing) and the introduction, analysis and interpretation of the data in addition to performance in the lab class and the accuracy of the data produced. The assessment included both individual and group aspects. Videos were worth $3.5 \%$ ( $2^{\text {nd }}$ year) and $4 \%$ $\left(3^{\text {rd }}\right.$ year) of the students grade for the semester. 
EGFR prac video assessment marking rubric (/100)

\begin{tabular}{|c|c|c|c|c|c|}
\hline $\begin{array}{l}\text { Lab performance } \\
(20)\end{array}$ & $\begin{array}{l}\text { Punctual. Well organised in } \\
\text { the lab. High standard of } \\
\text { technical ability. Very } \\
\text { engaged in class activity. } \\
\text { Good attitude. } 20\end{array}$ & $\begin{array}{l}\text { Poor performance in ONE of: } \\
\text { punctuality, organisation in } \\
\text { the lab, technical ability, } \\
\text { attitude to class. } 15\end{array}$ & $\begin{array}{l}\text { Poor performance in MORE } \\
\text { than one of : punctuality, } \\
\text { organisation in the lab, } \\
\text { technical ability, attitude to } \\
\text { class } \mathbf{1 0}\end{array}$ & $\begin{array}{l}\text { Poor performance across all } \\
\text { parameters. } \mathbf{5}\end{array}$ & Experiment not performed. $\mathbf{0}$ \\
\hline $\begin{array}{l}\text { VIDEO -Overall } \\
\text { quality of production } \\
\text { (5) }\end{array}$ & $\begin{array}{l}\text { The quality of the production } \\
\text { is excellent. Cohesive } \\
\text { presentation demonstrates } \\
\text { planning and shows care and } \\
\text { effort has been taken. } 5\end{array}$ & $\begin{array}{l}\text { The quality of the production } \\
\text { is good with few issues. The } \\
\text { video shows some planning } \\
\text { and care and effort have been } \\
\text { taken. } 4\end{array}$ & $\begin{array}{l}\text { The quality of the production } \\
\text { is acceptable with some } \\
\text { issues regarding quality and } \\
\text { organisation. } 3\end{array}$ & $\begin{array}{l}\text { The quality of the production } \\
\text { is poor. Disjointed } \\
\text { presentation demonstrates } \\
\text { little care or effort. Little } \\
\text { evidence of planning. } 2\end{array}$ & Video not submitted. $\mathbf{0}$ \\
\hline VIDEO - Audio (5) & $\begin{array}{l}\text { The audio is very clear and } \\
\text { effectively communicates the } \\
\text { main ideas. The quality } \\
\text { including: high or low sound } \\
\text { levels, background noise, } \\
\text { hiss, poor cuts and fades } \\
\text { long periods of silence, } \\
\text { unbalanced etc. is of a very } \\
\text { high standard. The speech is } \\
\text { fluent and the speed of } \\
\text { delivery is very } \\
\text { understandable. } 5\end{array}$ & $\begin{array}{l}\text { The audio is clear and } \\
\text { assists in communicating the } \\
\text { main ideas. The quality } \\
\text { including: high or low sound } \\
\text { levels, background noise, } \\
\text { hiss, poor cuts and fades } \\
\text { long periods of silence, } \\
\text { unbalanced etc. is } \\
\text { appropriate. The speech is } \\
\text { fluent and the speed of } \\
\text { delivery is acceptable. } 4\end{array}$ & $\begin{array}{l}\text { The quality of the audio is } \\
\text { acceptable with some issues } \\
\text { regarding quality including: } \\
\text { high or low sound levels, } \\
\text { background noise, hiss, poor } \\
\text { cuts and fades long periods } \\
\text { of silence, unbalanced etc. } \\
\text { The speech is fluent but has } \\
\text { some pauses, hums etc. The } \\
\text { speed of delivery is } \\
\text { acceptable. } 3\end{array}$ & $\begin{array}{l}\text { The audio is inconsistent in } \\
\text { clarity (too loud/too } \\
\text { soft/garbled) at times i.e. } \\
\text { high or low sound levels, } \\
\text { background noise, hiss, poor } \\
\text { cuts and fades long periods } \\
\text { of silence, unbalanced etc. } \\
\text { The speech lacks fluency, is } \\
\text { punctuated by pauses, hums } \\
\text { etc. The speed of delivery is } \\
\text { too slow or rushed. } 2\end{array}$ & No audio included on video $\mathbf{0}$ \\
\hline VIDEO - Visuals (5) & $\begin{array}{l}\text { The visual presentation } \\
\text { assists in presenting an } \\
\text { overall theme that appeals to } \\
\text { the audience and enhances } \\
\text { concepts with a high impact } \\
\text { message. Visual } \\
\text { presentations explain and } \\
\text { reinforce key points } 5\end{array}$ & $\begin{array}{l}\text { The visual presentation } \\
\text { depicts material and assist } \\
\text { the audience in } \\
\text { understanding the flow of } \\
\text { information and content. } \\
\text { Production could be } \\
\text { enhanced by the inclusion of } \\
\text { images improved } \\
\text { images/graphics etc. } 4\end{array}$ & $\begin{array}{l}\text { Some of the visual } \\
\text { presentation seems unrelated } \\
\text { to the topic or do not } \\
\text { enhance concepts or are } \\
\text { distracting decorations that } \\
\text { detract from the content } 3\end{array}$ & $\begin{array}{l}\text { Visuals do not enhance } \\
\text { understanding of the content, } \\
\text { and are distracting } \\
\text { decorations that detract from } \\
\text { the content. } 2\end{array}$ & Video not included $\mathbf{0}$ \\
\hline VIDEO - Timing (5) & $\begin{array}{l}\text { Video was precisely within } \\
\text { the timeline and appropriate } \\
\text { timing was given to all } \\
\text { sections and was paced very } \\
\text { well. } 5\end{array}$ & $\begin{array}{l}\text { Video was within the timeline } \\
\text { and reasonable timing was } \\
\text { given to all sections and } \\
\text { pacing was acceptable. } 4\end{array}$ & $\begin{array}{l}\text { Video was much longer or } \\
\text { shorter than the guidelines } \\
\text { OR imbalanced between } \\
\text { sections OR the speed of } \\
\text { delivery varied extensively } \\
\text { between too slow or rushed. } \\
\mathbf{3}\end{array}$ & $\begin{array}{l}\text { Video was much longer or } \\
\text { shorter than the guidelines } \\
\text { with an imbalance between } \\
\text { sections. The speed of } \\
\text { delivery varied extensively } \\
\text { between too slow or rushed. } \\
2\end{array}$ & Video not submitted. 0 \\
\hline $\begin{array}{l}\text { VIDEO - Introduction } \\
(10)\end{array}$ & $\begin{array}{l}\text { The introduction is very clear } \\
\text { and coherent and evokes } \\
\text { interest in the topic. The } \\
\text { introduction orients the } \\
\text { audience to what is to follow. } \\
\mathbf{1 0}\end{array}$ & $\begin{array}{l}\text { The introduction is clear and } \\
\text { coherent and orients the } \\
\text { audience to what is to follow. } \\
8\end{array}$ & $\begin{array}{l}\text { The introduction is confusing } \\
\text { OR does not make the topic } \\
\text { interesting OR does not } \\
\text { orient the audience to what is } \\
\text { to follow. } 6\end{array}$ & $\begin{array}{l}\text { The introduction is confusing } \\
\text { AND does not make the topic } \\
\text { interesting AND does not } \\
\text { orient the audience to what is } \\
\text { to follow. } 4\end{array}$ & $\begin{array}{l}\text { Introduction not included on } \\
\text { video. } \mathbf{0}\end{array}$ \\
\hline Data (10) & $\begin{array}{l}\text { Accurate data reflecting } \\
\text { ability to follow procedures \& } \\
\text { competently use equipment. } \\
\text { Data presented in a very clear } \\
\text { manner that was easy to } \\
\text { understand. } 10\end{array}$ & $\begin{array}{l}\text { Minor inaccuracies in data } \\
\text { reflecting errors in procedures } \\
\text { or use of equipment. OR data } \\
\text { presentation needing slight } \\
\text { improvements. } 8\end{array}$ & $\begin{array}{l}\text { Inaccurate data reflecting a } \\
\text { lack of ability to follow } \\
\text { procedures \& incompetent } \\
\text { use equipment OR data } \\
\text { presentation very difficult to } \\
\text { understand. } 6\end{array}$ & $\begin{array}{l}\text { Inaccurate data reflecting a } \\
\text { lack of ability to follow } \\
\text { procedures \& incompetent } \\
\text { use equipment. Data } \\
\text { presentation very difficult to } \\
\text { understand. } 4\end{array}$ & Data not presented. $\mathbf{0}$ \\
\hline $\begin{array}{l}\text { VIDEO - Analysis \& } \\
\text { interpretation of } \\
\text { data (40) }\end{array}$ & $\begin{array}{l}\text { Accurate with appropriate } \\
\text { detail provided. Data } \\
\text { generated discussed in terms } \\
\text { of results expected. } \\
\text { Questions answered } \\
\text { accurately demonstrating an } \\
\text { ability to analyse and } \\
\text { interpret the experimental } \\
\text { data and integrated into } \\
\text { discussion. High level of } \\
\text { science concept } \\
\text { understanding is apparent. } \\
\text { Information is accurate and } \\
\text { thorough, but concise. } 40\end{array}$ & $\begin{array}{l}\text { Minor inaccuracies in either } \\
\text { analysis or interpretation of } \\
\text { data. } 30\end{array}$ & $\begin{array}{l}\text { Incorrect interpretation of data } \\
\text { demonstrating a poor ability } \\
\text { to analyse or interpret the } \\
\text { experimental data. } \\
\text { Discussion not addressing all } \\
\text { required points. } 20\end{array}$ & $\begin{array}{l}\text { Information is inaccurate. } \\
\text { Demonstrates a } \\
\text { misunderstanding of } \\
\text { experimental design and } \\
\text { theoretical knowledge. } \mathbf{1 0}\end{array}$ & \begin{tabular}{|l|} 
Data analysis and \\
interpretation not included. $\mathbf{0}$
\end{tabular} \\
\hline
\end{tabular}

Figure 2. Assessment rubric

\subsection{Evaluation}

\subsubsection{Classroom Observations}

Informal observation of student behaviour in the specific laboratory classes was recorded by the unit co-ordinators (Authors CJS and JOM) and the teaching associates involved in delivering the classes and marking the video assessments. The unit co-ordinators and many of the teaching associates had taught and assessed these practical classes in previous years. Although the Moodle forums were available for discussion of technical issues, there was very little use of the forum and students did not appear to have difficulties with the technical aspects of filming and editing their videos. 


\subsubsection{Student Marks}

The student marks for the same practical assessed by written reports $(n=92)$ and the video reports $(n=74)$ in consecutive years of $3^{\text {rd }}$ year biochemistry classes were examined. Differences in students grade distributions between those assessed by written report or video reports were analysed by one-tailed t-tests. We selected the $3^{\text {rd }}$ year cohorts as they were close to completing their science degrees and potentially seeking employment in science-related fields where creativity and critical thinking are important attributes sought by employers.

\subsubsection{Surveys}

Student's perceptions of the video assessment were measured using online surveys (www.surveymonkey.com). Students were invited via Monash University's virtual learning environment, Moodle, to anonymously complete a short survey that contained both closed and open-ended questions. Both $2^{\text {nd }}$ and $3^{\text {rd }}$ year cohorts were invited to complete the survey after the video assessment was submitted. The same survey was delivered to both student cohorts but with separate links to identify the cohort year. The data was analysed using Microsoft Excel. Open- ended questions were qualitatively analysed by thematic analysis. Human ethics permission was obtained through the Monash University Human Research Ethics Committee.

\section{Results and Discussion}

Observation of student behaviour during the laboratory classes found students enjoyed filming/photographing their experiments (Figure 3) and appeared far more engaged with the actual experiments than in previous years (personal communication).

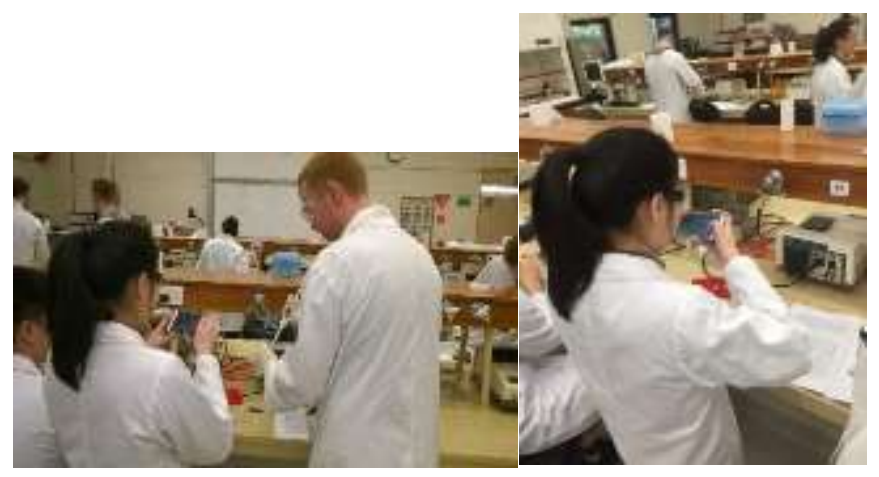

Figure 3. Biochemistry $3^{\text {rd }}$ year students filming/photographing their experimental work (reproduced with students' permission).

The quality of the student-produced videos was very high and many teaching associates who graded them commented on the high level of data analysis and critical thinking exhibited by the students as well as how creative the videos were. Figure 4 shows still images from a video prepared by $2^{\text {nd }}$ year students. This video was highly creative and both students demonstrated a very high level of critical thinking in the analysis of the data.
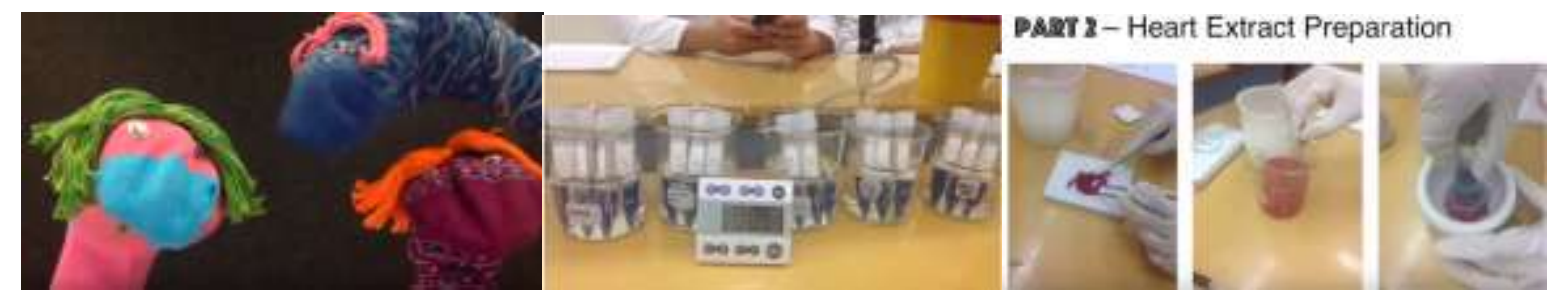

Figure 4. Still images from a $2^{\text {nd }}$ year biochemistry student produced video (reproduced with students' permission).

A comparison was made of two separate third-year biochemistry (BCH3042) cohorts who completed the same laboratory practical and were assessed by either traditional written report $(n=92)$ or by student produced videos $(n=74)$. Figure 5 shows the percentage of students that obtained grades for their laboratory report within each grade range. Although the data compares cohorts that completed the same laboratory practical across two separate years, the graph shows that the percentage of students that obtained grades above $90 \%$ was significantly higher $(\mathrm{p}<0.05)$ for the video 
assessment practical than for students who wrote a traditional lab report. Of particular interest, none of the students from the cohort who produced videos for their assessment received a grade below $80 \%$ whereas many students who produced written reports received grades well below $80 \%$. This could be cohort specific but could also result from the fact that students who produced videos engaged with the laboratory classes to a greater extent and critically and creatively analysed the methods and data to a much higher extent than students who answered questions in written form.

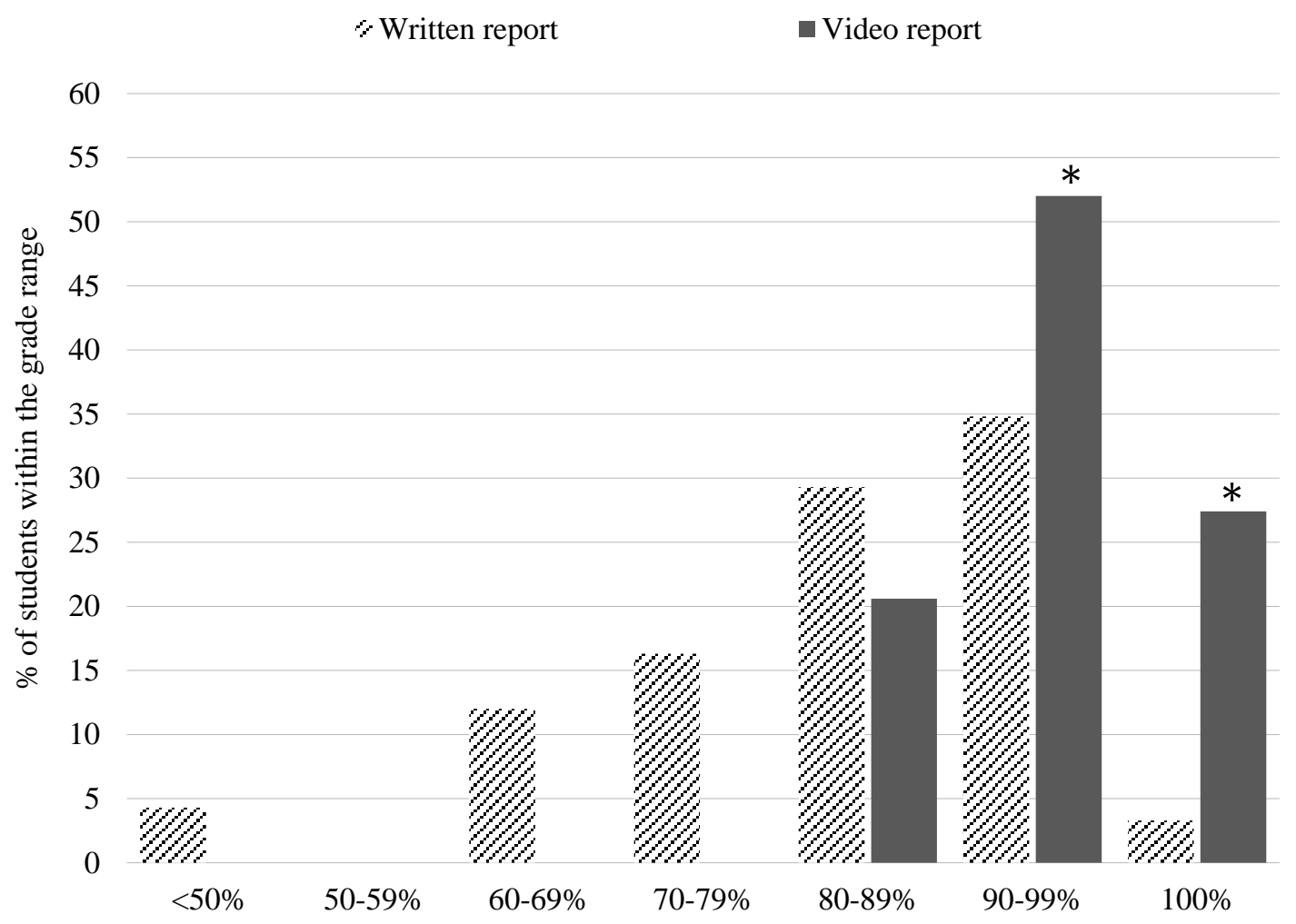

Student grade range for laboratory report

Figure 5. Comparison of student grades from two $3^{\text {rd }}$ year biochemistry cohorts that were assessed on the same practical by traditional written report (light bars) versus a student produced video report (dark bars). $* \mathrm{p}<0.05$ using a one-tailed t-test.

\subsection{Student Perceptions of Video Assessment}

The student response rates for the voluntary, anonymous, online surveys, completed out of class time, varied between $32 \%$ ( $3^{\text {rd }}$ year) and $18 \%$ ( $2^{\text {nd }}$ year). Although the response rate is low, the data can be viewed under the lens of representative samples from the two student populations $\left(2^{\text {nd }}\right.$ and $3^{\text {rd }}$ year $)$.

When students (combined $2^{\text {nd }}$ and $3^{\text {rd }}$ year student cohorts) were asked if the use of videos was an interesting approach to assessment 53\% strongly agreed/agreed (Figure 6). Of the remaining respondents, $18 \%$ were unsure and $29 \%$ disagreed/strongly disagreed. 


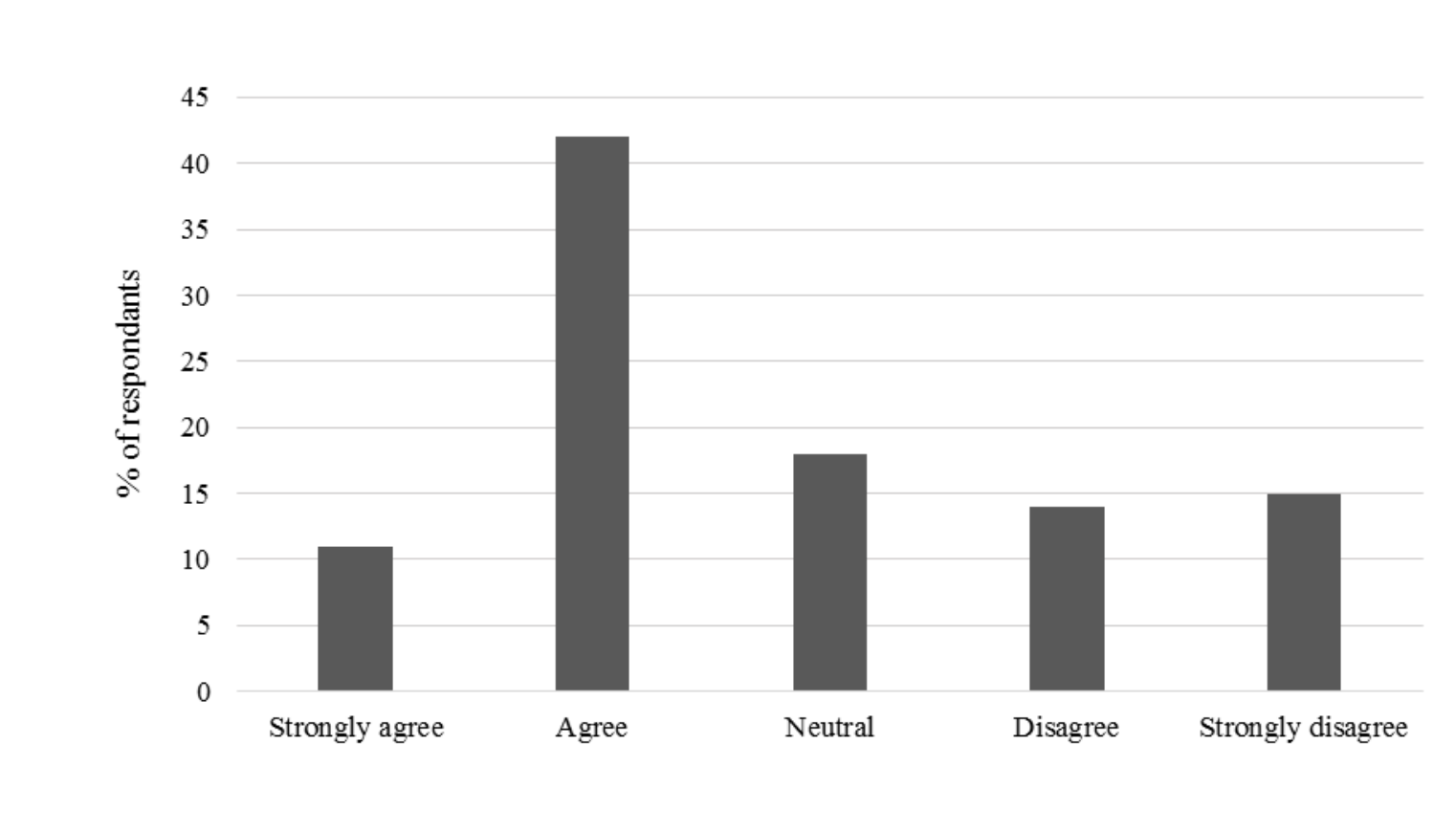

Figure 6. Video reports were an interesting approach to assessment.

Response rate $(\mathrm{n}=65)$ to the statement "The video report was an interesting approach to assessment".

When asked if the video assessment allowed them to think creatively, 59\% of the combined cohorts strongly agreed/agreed whereas only $27 \%$ disagreed/strongly disagreed (Figure 7). This was a positive outcome as the video reports were designed to encourage a creative approach to presenting results. A possible reason as to why students disagreed or were unsure if the video report allowed them to think creatively could be that students doubted their own abilities to think creatively and did not recognise their work as being creative.

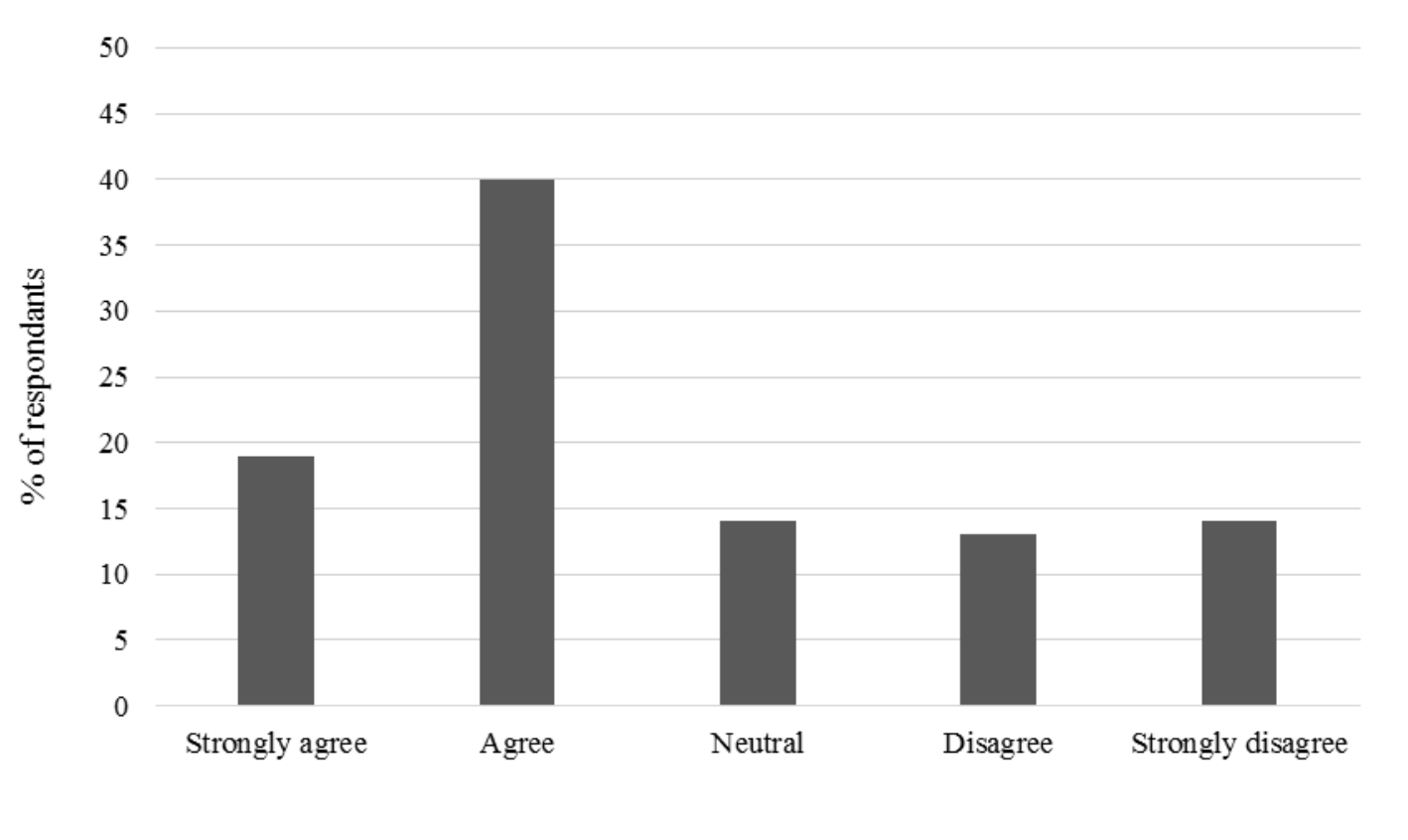

Figure 7. Preparing the video report allowed the students to think creatively.

Response rate ( $\mathrm{n}=65)$ to the statement "Preparing the video report allowed me to think creatively". 
The students were also asked to assess the value of the video report as a learning experience. While $42 \%$ of the combined cohorts strongly agreed/agreed that it was a valuable learning experience, $31 \%$ were unsure and $27 \%$ of students disagreed/strongly disagreed (Figure 8). One theory could be that they did not understand or fully appreciate the aims of the video report were to enhance data analysis, critical thinking and creativity. The potential lack of understanding or appreciation did not reflect in their grades as all of the $3^{\text {rd }}$ year cohort received above $80 \%$ for their video report (Figure 5).

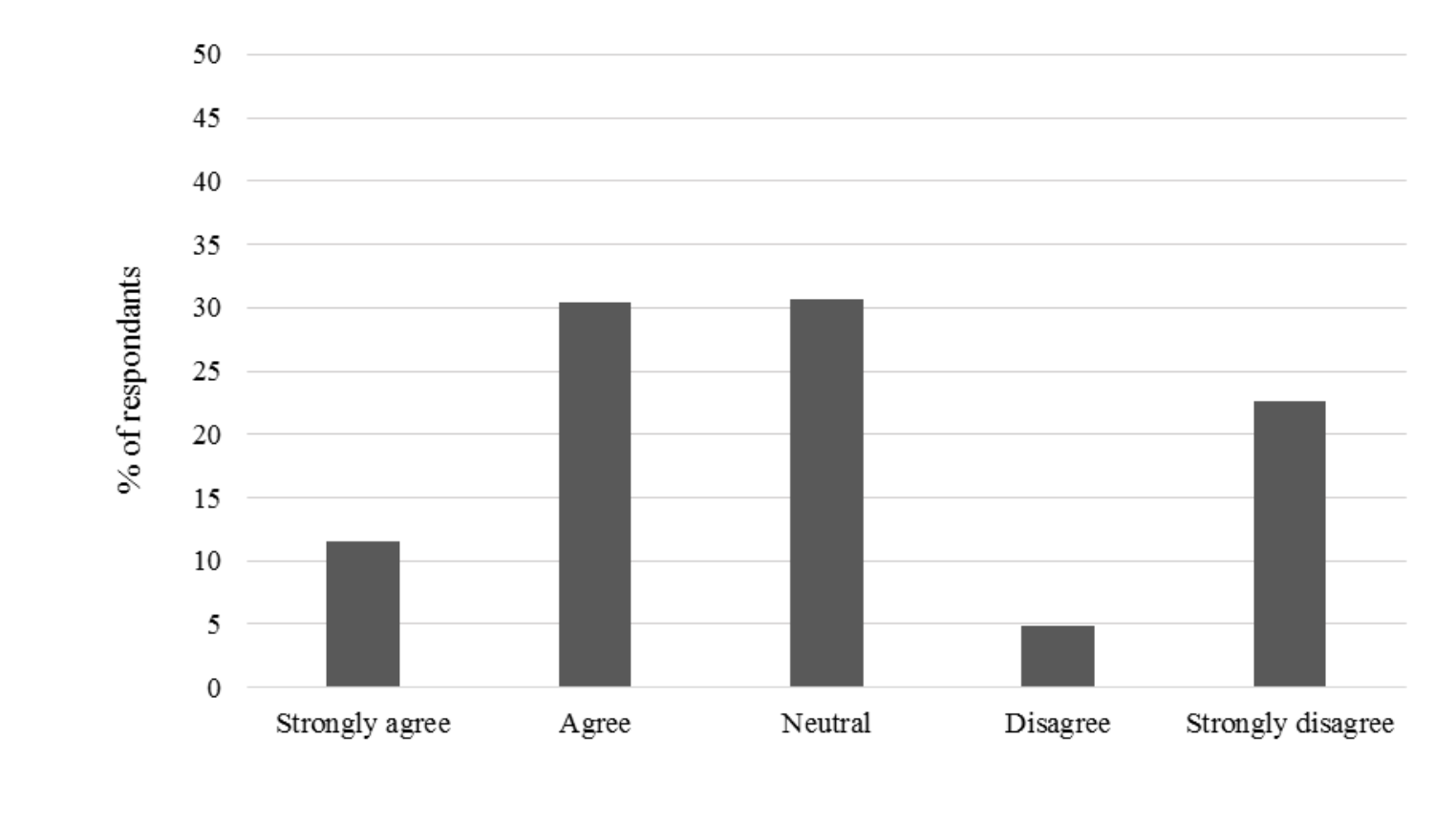

Figure 8. The video report was a valuable learning experience.

Response rate $(\mathrm{n}=65)$ to the statement "The video report was a valuable learning experience".

The time required to complete the video report was a concern of many students. Of the combined cohorts responses, $35 \%$ reported that the video report took a long time to complete and $16 \%$ commented (open-ended questions) that it would have been much quicker to prepare a written report. To complete the video report students had to both film and edit and when specifically asked about the editing process and how many edits of their video it took to produce their final version, differences were seen between the two cohorts ( $2^{\text {nd }}$ and $3^{\text {rd }}$ year). $54 \%$ of the $3^{\text {rd }}$ year cohort made 3 or more edits to finish their video whereas only $34 \%$ of $2^{\text {nd }}$ year students made 3 or more edits. In contrast, only $21 \%$ of $3^{\text {rd }}$ years completed their videos in $0-1$ edits compared to $44 \%$ of $2^{\text {nd }}$ years who completed their videos in $0-1$ edits. This suggests that the $3^{\text {rd }}$ year cohort were spending a lot longer (on average) on editing and completing their videos for submission. One explanation for this could be that a number of the $2^{\text {nd }}$ year students had taken a previous unit that involved the production of digital animations and hence they had some previous experience with video editing.

From an educators (the authors) perspective, the time and effort put into producing the videos could be viewed as a positive outcome as represented by the level of data analysis, critical thinking and high quality presentation of the video reports. However many students did not agree that the time spent was worth the weighting of the practical exercise (3.5\% ( $2^{\text {nd }}$ year) or $4 \%\left(3^{\text {rd }}\right.$ year $)$ ) and were quite disgruntled as it added significantly to their workload. This was apparent in the findings that $31 \%$ of students rated the overall student produced video report as poor to very poor (Figure 9). In contrast, $49 \%$ of both cohorts rated the video report as good/excellent and enjoyed the experience. 


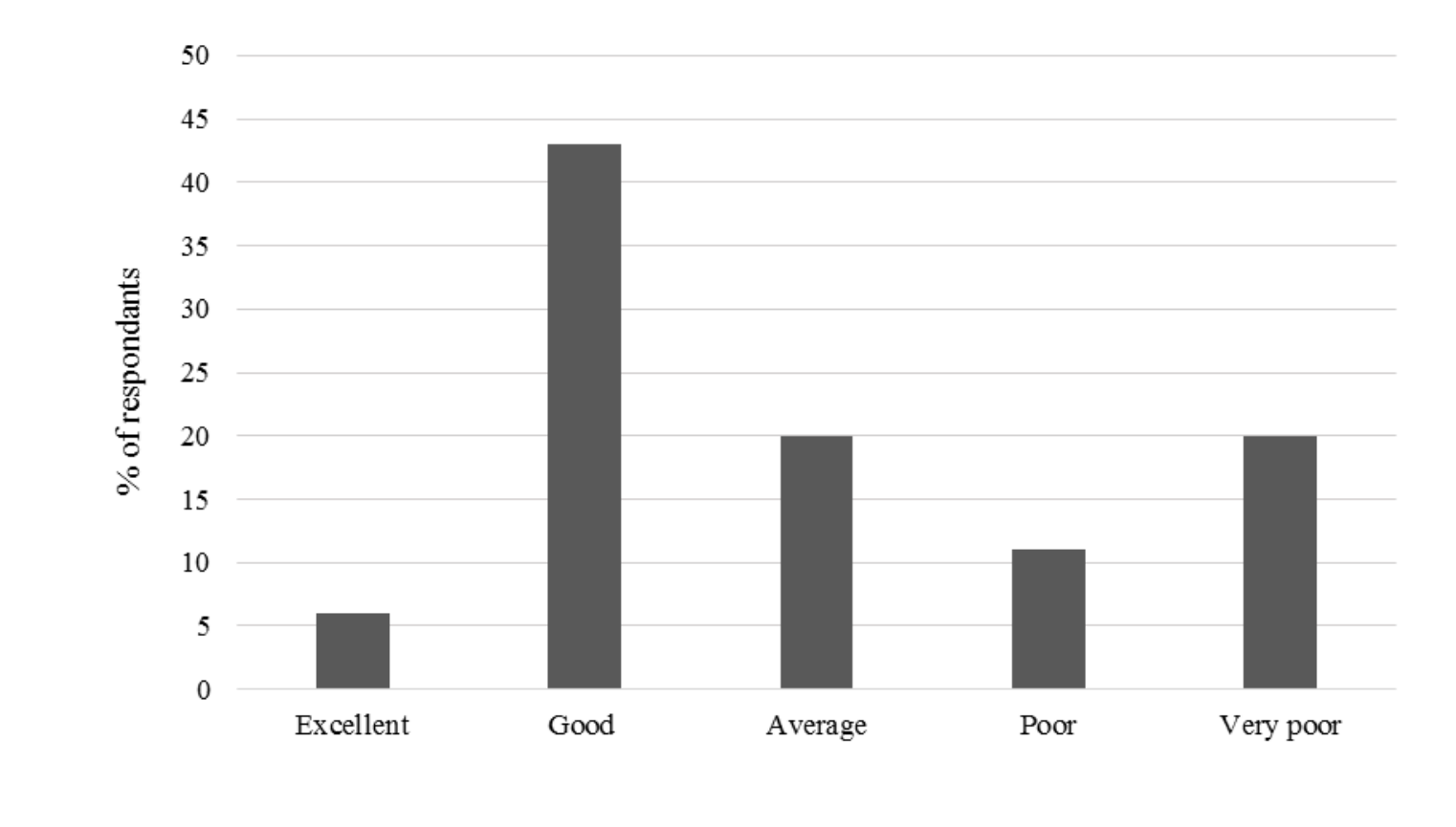

Figure 9. Overall rating of the student produced video report as a learning experience.

Response rate $(n=65)$ to the statement "Overall as a learning experience I would rate the video report as:"

Students were asked to reflect on the video assessment.

When asked, "What aspects of the practical did you find most enjoyable and interesting?" responses included:

"The creative process and trying to communicate the results in a way that was understandable to the viewer".

"The experiment itself was quite fun, and preparing the video was a nice change"

"The aspect of applying critical thinking to refine the content being discussed."

"Taking photos for visual presentation and being able to explain them in methodology and discussion"

"recording and presenting information visually"

"It made us think more deeply about the results, and come up with ways to explain the results in a concise and understandable way"

"Dissecting the material to best communicate what was happening visually"

"The most enjoyable and interesting part was creating and filming the video. It enables student to take time and analyse the whole practical"

Thematic analysis of the student reflections $(n=51)$ to the question "What aspects of the practical did you find most enjoyable and interesting?" revealed that $24 \%$ of the combined $2^{\text {nd }}$ and $3^{\text {rd }}$ year cohorts found the practical exercise to be "fun/enjoyable". Other themes that emerged were that the practicals were "creative" (12\%) and "interesting" (10\%).

However not all students liked the innovative assessment and in fact a small cohort were very unhappy with the introduction of this video project, in particular with the increased workload.

When asked, "What aspects of the practical need improvement and what changes would you suggest?"

"None worst assignment ever"

"I found the process tedious and needlessly time consuming compared to a normal practical"

"This was a horrible assessment, not only are group projects difficult to organise with a group who have busy uni and work timetables but to set aside hours to film together was such a headache. Please understand this is not viable when science students have such long contact hours, it was almost impossible to find enough time to catch up to film for the several hours we required" 
"Time consuming compared to normal report. A lot of time taken to record and edit. "

"Longer period of time for collaboration and working on the video. "

"It was brutally time-consuming on account of (1) the editing and (2) all things not related to the biochemistry"

"To be provided with examples in class possibly of what we should be trying to achieve in our presentation for some inspiration."

"Stick to the standard scientific report"

Thematic analysis of student reflections $(n=49)$ to the question "What aspects of the practical need improvement and what changes would you suggest?" revealed "time/time consuming" in 71\% of the responses. Many of the negative comments came from the $3^{\text {rd }}$ year cohort as many took longer to complete their videos compared to the $2^{\text {nd }}$ year cohort (54\% versus $34 \%$ respectively for 3 or more edits). Although they received very high grades for their reports and demonstrated engagement, critical thinking and creativity they were not happy with the time it took and would have much rather prepared a written report. Some of the $3^{\text {rd }}$ year students spent up to 7 hours compiling their videos (which were excellent) but well above the expected 2-3 hours required to produce them. In addition, the $3^{\text {rd }}$ year students were six weeks away from completing their degree and many did not see the benefits in learning how to make videos or the learning benefits that the video assessment offered. Furthermore, the $3^{\text {rd }}$ year cohort were given one week to complete their videos compared to 2 weeks for the $2^{\text {nd }}$ year cohort. This was because the $3^{\text {rd }}$ year students had other assignments to complete the week after the video due date so we did not want to overload them. In hindsight, the $3^{\text {rd }}$ years should have had 2 weeks to produce their videos as they felt rushed and spent many hours editing their videos to critically analyse and concisely present the data in order to stay within the 5-10 minute time limit. Meeting up with their practical partners during and outside of university hours was also a problem for some students. Many of the $2^{\text {nd }}$ year students were much more accepting of the time and effort as they were only mid-way through their degrees and seemed to accept the time spent producing the videos in and out of class as part of their required workload.

\section{Conclusion}

A novel innovative student produced video assessment task was introduced into a laboratory class for $2^{\text {nd }}$ and $3^{\text {rd }}$ year biochemistry students at Monash University. Overall, the students produced high quality videos and demonstrated engagement, data analysis skills, creativity and critical thinking. Although the students engaged in the laboratory experiments and enjoyed taking photos and film clips of their work, the video assessment was received with mixed reactions from the students. Issues arose for some students when compiling their videos and the time it took to do so hence there are aspects to be improved. Issues to be addressed include: student workload, assessment criteria and technological support. Addressing these issues will allow for further improvements in the student produced video assessment and the possible introduction into other laboratory science classes leading to improved creativity and critical thinking skills for Monash University science graduates.

\section{Acknowledgments}

This research was supported by a Monash University Faculty of Medicine, Nursing and Health Sciences Learning and Teaching Research Grant.

Thank you to Rob Macaulay for hand drawing the diagram of the process of the production of the student produced videos (Figure 1).

Thank you to Brendan Wilding for technological assistance.

\section{References}

Boud, D. \& Associates. (2010). Assessment 2020: Seven propositions for assessment reform in higher education. Sydney: Australian Learning and Teaching Council.

Box, M.C. Cathi L. Dunnagan' C.L., Hirsh, L.A.S, Cherry, C.R., Christianson, C.A., Gibson, R.J., Wolfe, M.I. \& Gallardo-Williams, M.T. (2017). Qualitative and Quantitative Evaluation of Three Types of Student-Generated Videos as Instructional Support in Organic Chemistry Laboratories. J. Chem. Educ, 94(2), 164-170. https://doi.org/10.1021/acs.jchemed.6b00451

Earl, L.M. (2012). Assessment as learning: Using classroom assessment to maximize student learning. (2nd ed). Corwin Press.

Erdmann, M.A. \& March, J.L. (2014). Video reports as a novel alternate assessment in the undergraduate chemistry laboratory. Chem. Educ. Res. Pract., 15, 650-657. https://doi.org/10.1039/C4RP00107A 
Fortman J. J. \& Battino R. J. (1990), A practical and inexpensive set of videotaped demonstrations, J. Chem. Educ., 67, 420-421. https://doi.org/10.1021/ed067p420

Hadzigeorgiou, Y., Fokialis, P., \& Kabouropoulou, M. (2012). Thinking about Creativity in Science Education. Creative Education, 3(5), 603-611. https://doi.org/10.4236/ce.2012.35089

Henderson, M. \& Phillips, M. (2015). Video-based feedback on student assessment:scarily personal. Australasian Journal of Educational technology, 31(1), 51-66. https://doi.org/10.14742/ajet.1878

Jensen, M., Mattheis, A., \& Johnson, B. (2012). Using student learning and development outcomes to evaluate a first-year undergraduate group video project. $C B E-$ Life Sciences education, 11, 68-80. https://doi.org/10.1187/cbe.11-06-0049

Kay, R.H. (2012). Exploring the use of videopodcasts in education: A comprehensive review. Computers in human behaviour, 28, 820-831. https://doi.org/10.1016/j.chb.2012.01.011

Parton,B.S., Crain-Dorough,M. \& Hancock, R. (2010). Using flip camcorders to create video feedback: Is it realistic for professors and beneficial to students? International Journal of Instructional Technology and Distance learning, 7(1), 15-23.

Pegrum, M., Bartle, E., \& Longnecker,N. (2015). Can creative podcasting promote deep learning? The use of podcasting for learning content in an undergraduate science unit. British Journal of Educational Technology, 46(1), 142-152. https://doi.org/10.1111/bjet.12133

Ryan, B. (2013). A walk down the red carpet: students as producers of digital video-based knowledge. Int. J. Technology Enhanced Learning, 5, 24-41. https://doi.org/10.1021/ed400715s

Smith, D.K. (2014). iTube, YouTube, WeTube: Social media videos in chemistry education and outreach. Journal of Chemical Education, 91, 1594-1599. https://doi.org/10.1021/ed400715s

Vanderlelie, J. (2013). Improving the student experience of learning and teaching in second year biochemistry: assessment to foster a creative application of biochemical concepts. International Journal of Innovation in Science and Mathematics Education, 21(4), 46 - 57.

Aligning course outcomes educational standards frameworks [Internet]. Australia; Monash University; 2017 Jun 26. Monash graduate attributes. 2017 June 26 [cited 2017 August 25]. Available from: http://www.monash.edu.au/pubs/handbooks/alignmentofoutcomes.html

www.surveymonkey.com 